\title{
ACAROLOGY
}

\section{Mite Diversity on Plants of Different Families Found in the Brazilian Atlantic Forest}

\author{
Tatiane M.M.G. de Castro ${ }^{1}$ and Gilberto J. de Moraes $^{2}$ \\ ${ }^{1}$ Depto. Fitossanidade, FCAV/ UNESP - Campus de Jaboticabal, 14884-900, Jaboticabal, SP \\ tatianemarie@yahoo.com.br \\ ${ }^{2}$ Depto. Entomologia, Fitopatologia e Zoologia Agrícola, ESALQ/USP, 13418-900, Piracicaba, SP \\ gjmoraes@esalq.usp.br; CNPqResearcher \\ Neotropical Entomology 36(5):774-782 (2007)
}

Diversidade de Ácaros em Plantas de Diferentes Famílias Encontrada na Mata Atlântica Brasileira

RESUMO - Este trabalho relata a ocorrência de ácaros predominantemente predadores, fitófagos e de hábitos alimentares variados em plantas encontradas na Mata Atlântica. O objetivo foi estimar o possível papel da vegetação da Mata Atlântica como reservatório desses grupos de ácaros que são também encontrados em plantas de importância agrícola. Foram tomadas amostras de 187 espécies de plantas pertencentes a 73 famílias em três tipos de vegetação da Mata Atlântica, de fevereiro de 2001 a outubro de 2002, obtendo-se o total de 2.887 ácaros pertencentes a 163 morfo-espécies de 16 famílias. A diversidade de ácaros foi alta, especialmente dos predadores; estes corresponderam a 1.562 espécimes de 92 morfo-espécies. Dentro desse grupo, Phytoseiidae representou $71 \%$ dos espécimes e $62 \%$ das morfo-espécies. Os ácaros fitófagos corresponderam a 836 espécimes de 36 espécies. Nesse grupo, a maior proporção de espécimes (61\%) correspondeu aos Tenuipalpidae, enquanto a maior proporção de espécies (64\%) correspondeu aos Tetranychidae. Os ácaros com hábitos alimentares variados corresponderam a 491 espécimes de 36 morfo-espécies. Dentro desse grupo, a maior proporção de espécimes (52\%) correspondeu aos Ascidae e a maior proporção de morfo-espécies (42\%) correspondeu aos Tydeinae (família Tydeidae). Alta abundância e riqueza de morfo-espécies de ácaros predominantemente predadores, fitófagos e de hábitos alimentares variados foram observados em 17 , cinco e nove espécies de plantas, respectivamente. Os resultados obtidos sugerem a importância das plantas da vegetação estudada como reservatório de ácaros predadores.

PALAVRAS-CHAVE: Acari, predador, controle biológico, floresta

ABSTRACT - This work reports the occurrence of mites predominantly predatory, phytophagous and with varied feeding habits on plants of the Atlantic Forest vegetation type of the State of São Paulo. The objective was to estimate the possible role of the Atlantic Forest vegetation as reservoir of these groups of mites which are also found on plants of agricultural importance. Samples were taken from 187 plant species belonging to 73 families in three vegetation types of the Atlantic Forest from February of 2001 to October of 2002. A total of 2,887 mites belonging to 163 morpho-species of 16 families were collected. Mite diversity was high, especially of predatory mites; these corresponded to 1,562 specimens of 92 morpho-species. Within this group, Phytoseiidae comprised $71 \%$ of the specimens and $62 \%$ of the morpho-species. Phytophagous mites comprised 836 specimens of 36 morpho-species. Within this group, Tenuipalpidae comprised the larger proportion of specimens $(61 \%)$ whereas Tetranychidae corresponded to the larger proportion of morpho-species (64\%). Mites with varied feeding habits corresponded to 491 specimens of 36 morpho-species. In this group, the larger proportion of specimens (52\%) consisted of Ascidae and the larger proportion of morpho-species (42\%) consisted of Tydeinae (family Tydeidae). High abundance and high morpho-species richness of mites of predominantly predatory, phytophagous and variable feeding habits were observed on 17, five and nine plant species, respectively. The results obtained suggest the importance of plants of the studied vegetation as reservoirs of predatory mites.

KEY WORDS: Acari, predator, biological control 
Mites of agricultural importance are generally classified either as phytophagous or predators. The most important superfamilies of exclusively phytophagous mites are Eriophyoidea and Tetranychoidea. The family Tarsonemidae also has many phytophagous species (Jeppson et al. 1975).

Plant inhabiting predatory mites are mostly of the family Phytoseiidae, which has great importance from an economic standpoint. Several phytoseiid mites are used for biological control of mite-pests (Moraes 2002). Other groups comprised of predominantly predatory species, especially Bdellidae, Cheyletidae, Cunaxidae, Stigmaeidae and Tydeidae of the subfamily Pronematinae are also common on plants. Other plant inhabiting mites show various feeding habits, including mycophagy and saprophagy etc. They are mostly represented by species of Acaridae, Ascidae, Winterschmidtiidae and Tydeidae of the subfamily Tydeinae (Gerson et al. 2003).

The Brazilian Atlantic Forest is one of the areas considered by Myers et al. (2000) as "hotspots", a term employed to refer to regions of the globe currently under strong anthropic pressure and which have high degree of biodiversity. Some efforts have been done in recent years to study the mites of the natural vegetation of the State of São Paulo, especially in Atlantic Forest areas. Recent works to determine mite species on Arecaceae and Euphorbiaceae have been conducted in that state by Gondim Jr. et al. (2000), Arruda Filho \& Moraes (2002), Navia \& Flechtmann (2002) and Zacarias \& Moraes (2002). This paper refers to a continuation of those studies, with determination of mite groups on plants of a relatively large number of families, located in the vicinity of the plants considered by those authors. The objective was to estimate the possible role of the Atlantic Forest vegetation as reservoir of mites of different groups which are also found on plants of agricultural importance.

\section{Material and Methods}

The work was carried out in the southwestern region of the State of São Paulo. Samples were collected from plants of the following vegetation types, which are some of the main environments of the Brazilian Atlantic Forest (IBGE 1992):

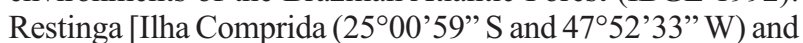
Cananéia $\left(24^{\circ} 53^{\prime} 35^{\prime \prime} \mathrm{S}\right.$ and $47^{\circ} 50^{\prime} 14^{\prime \prime} \mathrm{W} ; 24^{\circ} 57^{\prime} 32^{\prime \prime} \mathrm{S}$ and

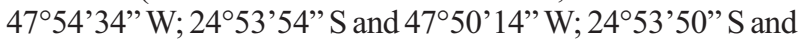
$47^{\circ} 50^{\prime} 18^{\prime \prime} \mathrm{W}$; and $24^{\circ} 54^{\prime} 06^{\prime \prime} \mathrm{S}$ and $\left.47^{\circ} 50^{\prime} 30^{\prime \prime} \mathrm{W}\right)$ ], Tropical Rain Forest [Pariquera-Açu (24'36'51' S and 47 $53^{\prime} 22^{\prime \prime}$ $\mathrm{W}$, and $24^{\circ} 36^{\prime} 50^{\prime \prime} \mathrm{S}$ and $47^{\circ} 52^{\prime} 45^{\prime}$ 'W)] and Seasonal Semideciduous Forest [Piracicaba (22 $42^{\prime} 30^{\prime \prime}$ S and $47^{\circ} 37^{\prime} 40^{\prime \prime}$ $\mathrm{W})$, Itu $\left(23^{\circ} 12^{\prime} 86^{\prime \prime} \mathrm{S}\right.$ and $\left.47^{\circ} 10^{\prime} 70^{\prime \prime} \mathrm{W}\right)$, Tapiraí $\left(24^{\circ} 01^{\prime} 47^{\prime}\right.$ '

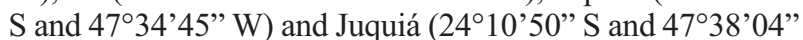
$\mathrm{W}$ and $24^{\circ} 12^{\prime} 34^{\prime \prime} \mathrm{S}$ and $\left.47^{\circ} 36^{\prime} 44^{\prime \prime} \mathrm{W}\right)$ ].

The samples were collected in February, March, April, June, July, October and December 2001 and March, April, July, August, September and October 2002. In the sampling process, a variable number of leaves of different ages were collected to allow, as much as possible, the determination of the existing mite diversity. They were taken at heights between 0.5 and 7 $\mathrm{m}$ from soil surface. The number of leaves per sample was variable between the different plant species as well as between the different sampling periods for each plant species.
Samples were taken from plants bearing flowers and/ or fruits on the sampling dates, thereby facilitating their identification. The sample of each plant was put in a paper bag that, in turn, was put into a polyethylene bag; all bags were put in a polystyrene cool box to maintain the temperature between 15 and $20^{\circ} \mathrm{C}$ during transport to the laboratory. The total numbers of samples taken from each locality were: Cananéia, 129; Ilha Comprida, 12; Itu, 16; Juquiá, 4; Pariquera-Açu, 192; Piracicaba, 20; and Tapiraí, 5. Samples were collected of a total of 187 plant species belonging to 73 families. The plant species sampled varied between sampling events.

In the laboratory, the mites were collected and mounted in Hoyer's medium for subsequent identification. All specimens collected were nominally identified to genera. The mites of each genus were separated in morpho-species. For the diversity analysis, Shannon-Wiener index (H') and uniformity index (J') were used. The theoretical maximum value of the Shannon-Wiener index (H'max) was calculated according to Krebs (1989).

Having the identification and the quantification of the mites collected, plant species considered important to maintain the diversity of mites of different feeding habits were determined. For such, the 5\% confidence intervals of the average number of specimens and of morpho-species of mites were calculated in relation to all plant species. Subsequently, the plants were classified according to the respective absolute values of those parameters in relation to their distribution around the corresponding averages. Plants for which those values were higher than the corresponding confidence interval upper limits were considered to have high abundance and morpho-species richness. The objective of this analysis was to have a parameter to select from all the plant species collected those that seem important as reservoir.

The specimens of each mite morpho-species were deposited in the mite reference collection of Departamento de Entomologia, Fitopatologia e Zoologia Agrícola, Escola Superior de Agricultura Luiz de Queiroz, Universidade de São Paulo, Piracicaba, SP, Brazil.

\section{Results}

In total, 2,887 mite specimens were collected, corresponding to 163 morpho-species of 70 genera in 15 families; because Tydeidae is represented by two subfamilies with different feeding habits, Pronematinae (predominantly predatory mites) and Tydeinae (mites with varied feeding habits), they are considered separately (Table 1). Considering all mites together, the diversity index corresponded to $83 \%$ of the estimated maximum theoretical diversity (uniformity index of 0.83 ).

The largest proportions of the specimens (54\%) and of the morpho-species (56\%) collected belong to families comprised predominantly by predatory species; this group of mites is subsequently mentioned in this paper just as "predatory mites". About $57 \%$ of the genera found in this study referred to families of predatory habits, which, however, corresponded only to $35 \%$ of the total number of families found in this study. Mites belonging to 

2002.

Table 1. Ecological parameters of mites found on plants of the Atlantic Forest of the State of São Paulo in 2001 and

\begin{tabular}{lccccccc}
\hline Parameters & \multicolumn{3}{c}{ Absolute numbers } & \multicolumn{3}{c}{ Proportions (\%) } \\
\hline & $\mathrm{P}$ & $\mathrm{Ph}$ & $\mathrm{V}$ & Total & $\mathrm{P}$ & $\mathrm{Ph}$ & $\mathrm{V}$ \\
\hline Abundance & 1,562 & 836 & 489 & 2,887 & 54 & 29 & 17 \\
Number of morpho-species & 92 & 36 & 35 & 163 & 56 & 22 & 22 \\
Number of genera & 40 & 12 & 18 & 70 & 57 & 17 & 26 \\
Number of families & $5(1)$ & 3 & $7(1)$ & $15(2)$ & 35 & 18 & 47 \\
(subfamilies of Tydeidae) & 1.62 & 1.25 & 1.01 & 1.84 & - & - & - \\
\hline H' & 1.96 & 1.56 & 1.54 & 2.21 & - & - & - \\
H'max & 0.82 & 0.80 & 0.66 & 0.83 & - & - & - \\
J' & & & & & & - \\
\hline
\end{tabular}

P: predominantly predator, Ph: phytophagous, V: varied feeding habits, H': Shannon- Wiener diversity index, H'max: maximum diversity, J': uniformity index

families composed by phytophagous species (Eriophyidae, Tenuipalpidae and Tetranychidae) corresponded to $29 \%$ of the specimens and to $22 \%$ of the morpho-species. Only about $17 \%$ of the genera and $18 \%$ of the families found in this study referred to phytophagous mites. Mites of families of variable feeding habits (Acaridae, Ascidae, Eupodidae, Erythraeidae, Tarsonemidae, Trombidiidae, Tydeidae-Tydeinae and Winterschmidtiidae) corresponded to $17 \%$ of the specimens and to $22 \%$ of the morpho-species collected. About $26 \%$ of the genera found in this study referred to families of mites with varied feeding habits, which, however, corresponded to $47 \%$ of the total number of families found in this study.

The Shannon-Wiener index (H') of the morpho-species of predatory mites (1.62) was higher than those of morphospecies of phytophagous mites (1.25) or mites of varied feeding habits (1.01). The diversity indexes of both predatory and phytophagous mites corresponded to about $80 \%$ of the corresponding estimated maximum theoretical diversities (uniformity indexes of 0.82 and 0.80 , respectively), while the diversity index of mites with varied feeding habits corresponded to about $66 \%$ of the estimated maximum theoretical diversity for that group (uniformity index of $0.66)$.

Predominant taxa. The Phytoseiidae comprised the vast majority of the specimens $(71 \%)$ and of the morphospecies $(62 \%)$ of predatory mites (Table 2$)$. In this family, the genera with the largest proportion of specimens were Amblyseius Berlese (19\%), Iphiseiodes De Leon (15\%) and Typhlodromips De Leon (12\%), whereas the genera with the largest proportion of morpho-species were Amblyseius (19\%), Proprioseiopsis Muma (12\%) and Euseius Wainstein $(11 \%)$.

Other common families of predatory mites found in this study were Cunaxidae and Stigmaeidae, each with $12 \%$ of the specimens. The cunaxid genera with the largest proportion of specimens were Scutopalus Den Heyer (46\%), Neocunaxoides Smiley (27\%) and Armascirus Den Heyer (10\%). The same genera, as well as Cunaxa Von Heyden, presented the highest proportion of morpho-species. Within the stigmaeids, Agistemus Summers had the largest proportion of specimens (96\%) and of morpho-species (67\%), followed by Zetzellia Oudemans (22\% of the specimens and 3\% of the morpho-species). Other taxa (Bdellidae, Cheyletidae and Tydeidae-Pronematinae) were much less represented.

The majority of the specimens of phytophagous mites collected belong to the Tenuipalpidae (61\%) (Table 3). Brevipalpus Donnadieu was by far the predominant genus in this family ( $82 \%$ of the specimens and $55 \%$ of the morphospecies), followed far behind by Tenuipalpus Donnadieu (10\% of the specimens and $36 \%$ of the morpho-species). The majority of the morpho-species of phytophagous mites collected belong to the Tetranychidae (64\%). Tetranychus Dufourt corresponded to the largest group in this family ( $51 \%$ of the specimens and $48 \%$ of the morpho-species), followed by Oligonychus Berlese (22\% of the specimens and $17 \%$ of the morpho-species). Eriophyidae was much less represented.

Out of the mites with varied feeding habits, Ascidae was the predominant family ( $52 \%$ of the specimens and $17 \%$ of the morpho-species) (Table 4). By far, most specimens of this family collected in this study belong to Asca Von Heyden $(82 \%)$. Tydeidae-Tydeinae was also quite well represented (31\% of the specimens and $42 \%$ of the morpho-species). Most of the specimens of this latter group collected in this study belong to Lorryia Oudemans (65\%). The other families of mites of variable feeding habits were much less represented.

Important plant species as mite reservoirs. Low but significant correlation $\left(\mathrm{R}^{2}=0.52 ; \mathrm{P}<.001\right)$ was observed between the numbers of mite specimens and morpho-species on each of the examined plant species. The most outstanding plant species that did not follow this pattern were Brunfelsia uniflora D.Don and Diatenopteryx sorbifolia Radlk., both with low abundances (13 specimens each) but with very high mite diversity (ten and nine morpho-species, respectively).

Concurrent high abundance and high diversity of predatory mites, phytophagous mites or mites of variable feeding habits were observed on 17 , five and nine plant 
Table 2. Number of specimens and morpho-species and the respective proportions (\%) of the families and the genera in each family of predominantly predatory mites collected on plants of the Atlantic Forest of the State of São Paulo in 2001 and 2002.

\begin{tabular}{|c|c|c|c|c|}
\hline \multirow{2}{*}{ Taxa } & \multicolumn{2}{|c|}{ Absolute numbers } & \multicolumn{2}{|c|}{ Proportions (\%) } \\
\hline & Specimens & Morpho-species & Specimens & Morpho-species \\
\hline Phytoseiidae & 1114 & 57 & 71 & 62 \\
\hline Amblyseius & 217 & 11 & 19 & 19 \\
\hline Iphiseiodes & 167 & 4 & 15 & 7 \\
\hline Typhlodromips & 133 & 4 & 12 & 7 \\
\hline Euseius & 102 & 6 & 9 & 11 \\
\hline Typhlodromalus & 96 & 3 & 9 & 5 \\
\hline Phytoseius & 83 & 5 & 7 & 9 \\
\hline Proprioseiopsis & 78 & 7 & 7 & 12 \\
\hline Neoparaphytoseius & 66 & 1 & 6 & 2 \\
\hline Amblydromalus & 61 & 4 & 5 & 7 \\
\hline Scapulaseius & 28 & 1 & 3 & 2 \\
\hline Phytoseiulus & 22 & 1 & 2 & 2 \\
\hline Leonseius & 14 & 1 & 1 & 2 \\
\hline Arrenoseius & 3 & 2 & 0 & 4 \\
\hline Typhlodromus & 3 & 1 & 0 & 2 \\
\hline Neoseiulus & 1 & 1 & 0 & 2 \\
\hline Paraphytoseius & 1 & 1 & 0 & 2 \\
\hline 4 new genera & 39 & 4 & 4 & 7 \\
\hline Cunaxidae & 195 & 15 & 12 & 16 \\
\hline Scutopalus & 89 & 2 & 46 & 13 \\
\hline Neocunaxoides & 53 & 2 & 27 & 13 \\
\hline Armascirus & 20 & 4 & 10 & 27 \\
\hline Cunaxa & 11 & 2 & 6 & 13 \\
\hline Scirula & 8 & 1 & 4 & 7 \\
\hline Pulaeus & 5 & 1 & 3 & 7 \\
\hline Rubroscirus & 5 & 1 & 3 & 7 \\
\hline Cunaxoides & 3 & 1 & 2 & 7 \\
\hline Pseudobonzia & 1 & 1 & 1 & 7 \\
\hline Stigmaeidae & 182 & 9 & 12 & 10 \\
\hline Agistemus & 175 & 6 & 96 & 67 \\
\hline Zetzellia & 5 & 2 & 3 & 22 \\
\hline Eustigmaeus & 2 & 1 & 1 & 11 \\
\hline Cheyletidae & 46 & 4 & 3 & 4 \\
\hline Mexecheles & 39 & 1 & 85 & 25 \\
\hline Chiapacheylus & 5 & 1 & 11 & 25 \\
\hline Cheyletus & 1 & 1 & 2 & 25 \\
\hline Oudemansicheyla & 1 & 1 & 2 & 25 \\
\hline
\end{tabular}


Table 2. Continuation.

\begin{tabular}{lcccc}
\hline \multirow{2}{*}{ Taxa } & \multicolumn{2}{c}{ Absolute numbers } & \multicolumn{2}{c}{ Proportions (\%) } \\
\cline { 2 - 5 } & Specimens & Morpho-species & Specimens & Morpho-species \\
\hline Bdellidae & 20 & 2 & 1 & 2 \\
Bdella & 12 & 1 & 60 & 50 \\
Cyta & 8 & 1 & 40 & 50 \\
Pronematinae & 5 & 5 & 0 & 5 \\
$\quad$ Pronematus & 4 & 4 & 80 & 80 \\
\multicolumn{1}{c}{ Parapronematus } & 1 & 1 & 20 & 20 \\
\hline Total & 1562 & 92 & - & - \\
\hline
\end{tabular}

Table 3. Number of specimens and morpho-species and the respective proportions (\%) of the families and the genera in each family of phytophagous mites collected on plants of the Atlantic Forest of the State of São Paulo in 2001 and 2002.

\begin{tabular}{lcccc}
\hline \multirow{2}{*}{ Taxa } & \multicolumn{2}{c}{ Quantities } & \multicolumn{2}{c}{ Proportions (\%) } \\
\cline { 2 - 5 } & Specimens & Morpho-species & Specimens & Morpho-species \\
\hline Tenuipalpidae & 508 & 11 & 61 & 31 \\
Brevipalpus & 419 & 6 & 82 & 55 \\
Tenuipalpus & 51 & 4 & 10 & 36 \\
\hline Ultratenuipalpus & 38 & 1 & 7 & 9 \\
Tetranychidae & 225 & 23 & 27 & 64 \\
\hline Tetranychus & 114 & 11 & 51 & 48 \\
Oligonychus & 50 & 4 & 22 & 17 \\
\hline Mononychellus & 17 & 1 & 8 & 4 \\
Neotetranychus & 16 & 2 & 7 & 9 \\
\hline Eutetranychus & 16 & 2 & 5 & 9 \\
Atrichoproctus & 11 & 2 & 0 & 4 \\
\hline Eotetranychus & 1 & 1 & 12 & 6 \\
\hline Eriophyidae & 103 & 2 & 62 & 50 \\
\hline Phyllocoptinae & 64 & 1 & 38 & 50 \\
\hline Cosella & 39 & 1 & - & - \\
\hline Total & 836 & 36 & & 9 \\
\hline
\end{tabular}

species of 13, four and seven plant families, respectively (Table 5). Although some of those plants were sampled several times in this study, which could account for the concurrent relatively high abundance and diversity of the mites they presented, most was sampled only once or twice. One plant species [Vernonia scorpioides (Lam.) Pers.] had concurrent high abundance and diversity of predatory as well as of phytophagous mites, while another plant species (Lantana camara L.) had concurrent high abundance and diversity of predatory mites as well as of mites of varied feeding habits.

Specifically in relation to predatory mites, L. camara was outstanding by having by far the highest number of specimens (99) and one of the highest number of morpho- species (8); 65\% of the specimens were Phytoseiidae and 32\% Cunaxidae. It was followed by Trichilia clausseni C.DC., with 37 specimens, belonging to nine species. As to the phytophagous mites, $V$. scorpioides was also outstanding by having the highest number of specimens (90) and of morphospecies (4); $70 \%$ of the specimens were Eriophyidae. It was followed by Trichilia elegans A.Juss., with 29 specimens, belonging to two species. None of the plant species was outstanding in relation to abundance or diversity of mites with varied feeding habits.

While few specimens and few species of mites were found on many plants sampled only once or twice, other plants also sampled few times had relatively high mite abundance and/ or diversity. Most outstanding in relation to abundance was 
Table 4. Number of specimens and morpho-species and the respective proportions (\%) of the families and the genera in each family of mites with varied feeding habits collected on plants of the Atlantic Forest of the State of São Paulo in 2001 and 2002.

\begin{tabular}{|c|c|c|c|c|}
\hline \multirow{2}{*}{ Taxa } & \multicolumn{2}{|c|}{ Quantities } & \multicolumn{2}{|c|}{ Proportions (\%) } \\
\hline & Specimens & Morpho-species & Specimens & Morpho-species \\
\hline Ascidae & 257 & 6 & 52 & 17 \\
\hline Asca & 211 & 2 & 82 & 33 \\
\hline Tropicoseius & 9 & 1 & 4 & 17 \\
\hline Lasioseius & 18 & 1 & 7 & 17 \\
\hline Proctolaelaps & 13 & 1 & 5 & 17 \\
\hline Rhinoseius & 6 & 1 & 2 & 17 \\
\hline Tydeinae & 151 & 15 & 31 & 42 \\
\hline Lorryia & 98 & 7 & 65 & 47 \\
\hline Afrotydeus & 37 & 2 & 25 & 13 \\
\hline Pretydeus & 6 & 2 & 4 & 13 \\
\hline Metatriophtydeus & 4 & 1 & 3 & 7 \\
\hline Tydeus & 3 & 1 & 2 & 7 \\
\hline Metapronematus & 1 & 1 & 1 & 7 \\
\hline Prelorryia & 2 & 1 & 1 & 7 \\
\hline Eupodidae & 30 & 4 & 6 & 11 \\
\hline Eupodes & 30 & 4 & 100 & 100 \\
\hline Tarsonemidae & 31 & 3 & 7 & 8 \\
\hline Fungitarsonemus & 16 & 1 & 52 & 33 \\
\hline Tarsonemus & 15 & 2 & 48 & 67 \\
\hline Winterschmidtiidae & 11 & 2 & 2 & 5 \\
\hline Czenspinskia & 6 & 1 & 55 & 50 \\
\hline Oulenzia & 5 & 1 & 45 & 50 \\
\hline Erythraeidae & 6 & 4 & 1 & 11 \\
\hline Acaridae & 4 & 1 & 1 & 3 \\
\hline Neotropacarus & 4 & 1 & 100 & 100 \\
\hline Trombidiidae & 1 & 1 & 0 & 3 \\
\hline Total & 491 & 36 & - & - \\
\hline
\end{tabular}

Endlicheria paniculata (Spreng.) J.F.Macbr., which, despite being sampled only once had very high mite abundance (126 specimens, $83 \%$ of which belonged to a single Tenuipalpidae species). As to diversity, plants sampled only once had from one to 10 mite morpho-species $($ mean $=2.5)$. The following plant species sampled only once had the highest mite diversity: Chrysophyllum gonocarpum Engl., E. paniculata, Metrodorea stipularis Mart. and Myrcia fallax DC. (five mite morphospecies); Esenbeckia leiocarpa Engl. and T. elegans (six morphospecies); Zanthoxylum rhoifolium Lam. (seven morpho-species); D. sorbifolia and Psidium guajava L. (nine morpho-species); Trichilia clausseni C.DC. and Trichilia pallida Sw. (10 morphospecies). Those diversity levels can be considered high, given the fact that $V$. scorpioides, the plant species with the highest diversity (19 morpho-species) in this study, it was sampled 13 times. Only on another plant species, Schinus terebinthifolius Raddi., more than 10 morpho-species (12 morpho-species) were found; however that plant was sampled five times.

\section{Discussion}

The diversity of the plant inhabiting mites found in this study was very high. The number of species collected corresponded to about $21 \%$ of the number reported by Flechtmann \& Moraes (1999) for the whole State of São Paulo. The high diversity was expected from the generic statements in the literature concerning diversity of organisms in tropical 
Table 5. Plant species on which high abundance and morpho-species richness of predominantly predatory mites, phytophagous mites and mites with varied feeding habits were observed in samples taken in the Atlantic Forest of the State of São Paulo in 2001 and 2002.

\begin{tabular}{|c|c|c|c|c|}
\hline \multirow{2}{*}{ Species } & \multirow{2}{*}{ Family } & \multirow{2}{*}{$\begin{array}{l}\text { Number of } \\
\text { samplings }^{1}\end{array}$} & \multicolumn{2}{|c|}{ Mites } \\
\hline & & & specimens & morpho-species \\
\hline \multicolumn{5}{|l|}{ Predominantly predatory mites } \\
\hline Lantana camara $\mathrm{L}$. & Verbenaceae & 4 & 99 & 8 \\
\hline Trichilia clausseni C.DC. & Meliaceae & 1 & 37 & 9 \\
\hline Inga edulis Mart. & Fabaceae & 3 & 34 & 5 \\
\hline Senna multijuga (Rich.) H.S.Irwin \& Barneby & Caesalpiniaceae & 2 & 33 & 7 \\
\hline Mucuna altissima Hook. \& Arn & Fabaceae & 3 & 33 & 5 \\
\hline Tibouchina multiceps Cogn. & Melastomataceae & 2 & 32 & 6 \\
\hline Trichilia pallida $\mathrm{Sw}$ & Meliaceae & 1 & 31 & 8 \\
\hline Begonia fischeri Otto & Begoniaceae & 2 & 31 & 4 \\
\hline Schinus terebinthifolius Raddi. & Anacardiaceae & 5 & 25 & 6 \\
\hline Rubus brasiliensis Mart. & Rosaceae & 4 & 25 & 5 \\
\hline Coussapoa microcarpa (Schott) Rizzini & Cecropiaceae & 3 & 23 & 7 \\
\hline Psidium guajava $L$. & Myrtaceae & 1 & 23 & 8 \\
\hline Metrodorea stipularis Mart. & Rutaceae & 1 & 22 & 4 \\
\hline Aureliana fasciculata Sendt. & Solanaceae & 5 & 19 & 7 \\
\hline Vernonia scorpioides (Lam.) Pers. & Asteraceae & 13 & 17 & 11 \\
\hline Brunfelsia uniflora D.Don & Solanaceae & 4 & 13 & 10 \\
\hline Myrcia fallax DC. & Myrtaceae & 1 & 13 & 5 \\
\hline \multicolumn{5}{|l|}{ Phytophagous mites } \\
\hline Vernonia scorpioides (Lam.) Pers. & Asteraceae & 13 & 90 & 4 \\
\hline Trichilia elegans A.Juss. & Meliaceae & 1 & 29 & 2 \\
\hline Pterolepis glomerata Triana & Melastomataceae & 2 & 28 & 3 \\
\hline Esenbeckia leiocarpa Engl. & Rutaceae & 1 & 25 & 3 \\
\hline Zanthoxylum rhoifolium Lam. & Rutaceae & 1 & 23 & 2 \\
\hline \multicolumn{5}{|l|}{ Mites with varied feeding habits } \\
\hline Lantana camara $\mathrm{L}$. & Verbenaceae & 4 & 18 & 2 \\
\hline Baccharis semiserrata DC. & Asteraceae & 1 & 17 & 2 \\
\hline Ocotea brachybotra $\mathrm{Mez}$ & Lauraceae & 1 & 17 & 2 \\
\hline Psychotria suterella Müll.Arg. & Rubiaceae & 2 & 14 & 2 \\
\hline Lantana trifolia $\mathrm{L}$. & Verbenaceae & 1 & 14 & 2 \\
\hline Schinus terebinthifolius Raddi. & Anacardiaceae & 5 & 12 & 5 \\
\hline Zanthoxylum rhoifolium Lam. & Rutaceae & 1 & 11 & 3 \\
\hline Mucuna altissima Hook. \& Arn & Fabaceae & 3 & 7 & 2 \\
\hline Esenbeckia leiocarpa Engl. & Rutaceae & 1 & 6 & 2 \\
\hline
\end{tabular}

${ }^{1}$ Number of sampling period in which samples of the respective plant was collected.

forests. It is possible that such high diversity is a function of the considerable diversity of plants sampled. A great diversity of plants leads to a great diversity of microhabitats that in turn can allow the establishment of a high number of mite species (Walter \& O'Dowd 1995), given the corresponding availability of highly variable food sources. 
A detailed study on the diversity of mites on Euphorbiaceae in the Atlantic Forest was conducted by Zacarias \& Moraes (2002). In that study, the determined diversity indexes were lower than found in the present work, possibly as a consequent to the far lower number of plant species considered in that work. Specifically in relation to the predatory mites, the diversity determined in this study was greater than that found in two studies previously conducted in the Atlantic Forest, both on lower numbers of plant species (Zacarias \& Moraes 2002, Gondim Jr \& Moraes 2001) belonging to only two families (Euphorbiaceae and Arecaceae, respectively). The habitats provided by the latter botanic families were probably less diversified compared to those provided by the several families sampled in this study. The diversity of the predatory mites found in this study is still much greater than what has been determined in agroecosystems in the State of São Paulo. It is particularly interesting the fact that one of the genus of predatory mites with highest abundance in this present study (Typhlodromips) is rarely found in those agroecosystems.

Differently from what is commonly observed in agroecosystems, marked abundance of phytophagous mites was not found in this work. Particularly striking was the low proportion of specimens of Tetranychidae, despite the corresponding relatively high proportion of morphospecies. Usually, the tetranychids are the main mite group in agroecosystems. Similar comments apply to Eriophyidae and Tarsonemidae. It seems noteworthy that Tenuipalpidae was the most abundant group of phytophagous mites, especially represented by morpho-species of Brevipalpus. Despite their importance on several crops, often as virus vectors (Kitajima et al. 2003), mites of this genus are rarely abundant in agriculture. The tenuipalpid Tenuipalpus heveae Baker is, however, generally found at high population levels in rubber tree monocultures (Feres et al. 2002, Ferla \& Moraes 2002). In the present study, morpho-species of Tenuipalpus were much less abundant than Brevipalpus. The great abundance of predators and their high diversity could be some of the factors responsible for the reduced abundance of phytophagous mites. The predatory mites could probably not be as abundant as determined in this study, if they just used prey mites as food. Other food sources provided by plants (e.g. pollen and nectar) probably played an important role in maintaining the populations of predatory mites, which in turn could help controlling the populations of phytophagous mites.

Some of the plant species collected in this study seemed to be particularly important as mite reservoirs. However it is possible that other plants also important could have not been detected, because of the methodology used. Samples were taken randomly, and it was not possible to standardize sampling efforts for each plant species while trying, at the same time, to evaluate the maximum possible number of those, given the complexity of the environment where this study was conducted. Rarer plants were sampled less often; as a consequence, chances of determining low mite abundance and low rates of diversity on those plants were high. Had they been sampled more often, higher abundance and diversity of mites would be expected. Nevertheless in terms of abundance, rarer plants could in fact be considered less important as reservoirs of mites in comparison with more numerous plants.
The results of this study suggest that the Atlantic Forest as a whole is an important reservoir of predatory mites, some of which may help in the control of pest mites in agroecosystems. Pragmatically, it would be important to consider the possible interest of growers for some of those plant species in relation to different aspects, such as their possible use as ornamentals, windbreaks, hedges, sources of food for bees and other pollinators etc. (Moraes et al. 2001). In fact, some of the plants determined in this study to have an apparently greater interest as reservoir of predators have already been reported as important for different purposes. Among those plants, P. guajava is extensively cultivated because of its fruits. B. uniflora, D. sorbifolia, E. leiocarpa, L. camara, M. stipularis Mart., S. terebinthifolius, Senna multijuga (Rich.) H.S.Irwin \& Barneby, T. clausseni and Z. rhoifolium are important ornamentals (Lorenzi 1992, Lorenzi \& Sousa 1995); C. gonocarpum and S. terebinthifolius were reported as sources of food for birds (Lorenzi 1992); Rubus brasiliensis Mart. produces edible fruits, appreciated by humans as well as by birds (Lorenzi 2002). Further studies should indicate whether the introduction of those plants in agroecosystem would be beneficial for the conservation of predators of pest mites.

\section{Acknowledgments}

To V.V. Souza, for the identification of the plant species. To L.V.F. da Silva, for his help in sampling and processing the material in the laboratory. To N.C. Mesa Zuluaga, A.C. Lofego, D.N.M. Ferreira. and A.F. Bordignon, for help in the identification of the Tenuipalpidae, Tarsonemidae, Eriophyoidea and Ascidae, respectively. This project was funded by Fundação de Amparo a Pesquisa do Estado de São Paulo (Fapesp), within the Biota/Fapesp program (http:// www.biota.org.br/info/index).

\section{References}

Arruda Filho, G.P. de \& G.J. de Moraes. 2002. Grupos de ácaros (Arthropoda, Acari) encontrados em Arecaceae da Mata Atlântica do Estado de São Paulo. Biota Neotrop. 2: 1-18.

Feres, R.J.F., D. de C. Rossa-Feres, R.D. Daud \& R.S. Santos. 2002. Diversidade de ácaros (Acari: Arachnida) em seringueiras (Hevea brasiliensis Muell. Arg., Euphorbiaceae) na Região Noroeste do estado de São Paulo, Brasil. Rev. Bras. Zool. 19: $137-144$

Ferla, N.J. \& G.J. de Moraes. 2002. Ácaros (Arachnida, Acari) da seringueira (Hevea brasiliensis Muell. Arg.) no estado do Mato Grosso, Brasil. Rev. Bras. Zool. 19: 867-888.

Flechtmann, C.H.W. \& G.J. de Moraes. 1999. Biodiversidade de ácaros no estado de São Paulo, p.58-63. In R.F. Brandão \& E.M. Cancello (eds.), Biodiversidade do estado de São Paulo: Síntese do conhecimento do final do século XX, 5: invertebrados terrestres. São Paulo, FAPESP, 279p.

Gerson, U., R.L. Smiley \& R. Ochoa. 2003. Mites (Acari) for pest control. Oxford, Blackwell Science (Wash. D. C.), 539p. 
Gondim Jr, M.G.C., C.H.W. Flechtmann \& G.J. de Moraes. 2000. Mite (Arthropoda: Acari) associates of palms (Arecaceae) in Brazil. IV. Descriptions of four new species in the Eriophyoidea. Syst. Appl. Acarol. 5: 99-110.

Gondim Jr, M.G.C. \& G.J. de Moraes. 2001. Phytoseiid mites (Acari: Phytoseiidae) associated with palm trees (Arecaceae) in Brazil. Syst. Appl. Acarol. 6: 65-94.

IBGE - Instituto Brasileiro de Geografia e Estatística. 1992. Manual técnico da vegetação brasileira. Rio de Janeiro, IBGE, 92p. (Série Manuais Técnicos em Geociências, 1).

Jeppson, L.R., H.H. Keifer \& E.W. Baker. 1975. Mite injurious to economic plants. University of California Press, Berkeley, $614 \mathrm{p}$.

Kitajima, E.W., C.M. Chagas \& J.C.V. Rodrigues. 2003. Brevipalpustransmitted plant virus and virus like diseases: Cytopathology and some recent cases. Exp. Appl. Acarol. 30: 135-160.

Krebs, C.J. 1989. Ecological methodology. New York, Harper Collins Press, 654p.

Lorenzi, H. 1992. Árvores brasileiras: Manual de identificação e cultivo de plantas arbóreas nativas do Brasil. Nova Odessa, Editora Plantarum, 352p.

Lorenzi, H. 2002. Plantas medicinais do Brasil: Nativas e exóticas cultivadas. Nova Odessa, Editora Plantarum, 512p.

Lorenzi, H. \& H.M. de Sousa. 1995. Plantas ornamentais do Brasil: Arbustivas, herbáceas e trepadeiras. Nova Odessa, Editora Plantarum, 720p.
Moraes, G.J. de. 2002. Controle biológico de ácaros fitófagos com ácaros predadores, p.225-237. In J.R.P. Parra, P.S.M. Botelho, B.S. Corrêa-Ferreira \& M.S. Bento (eds.), Controle biológico no Brasil: Parasitóides e predadores, São Paulo, Manole, 635p.

Moraes, G.J. de, M.S. Zacarias, M.G.C. Gondim Jr \& R.J.F. Feres. 2001. Papel da vegetação natural como reservatório de ácaros predadores, p.492-497. In VII Simpósio de Controle Biológico (SICONBIOL), Poços de Caldas, MG. São Paulo, CD-Rom Microservice, Tecnologia Digital AS.

Myers, M., R.A. Mittermeier, C.G. Mittermeier, G.A.B. da Fonseca \& J. Kent. 2000. Biodiversity hotspots for conservation priorities. Nature 403: 853-858.

Navia, D. \& C.H.W. Flechtmann. 2002. Mite (Arthropoda: Acari) associates of plants (Arecaceae) in Brasil: VI. New genera and new species of Eriophyidae and Phytoptidae (Prostigmata: Eriophyoidea). Int. J. Acarol. 28: 121-146.

Walter, D.E. \& D.J. O'Dowd. 1995. Life on the forest phylloplane: Hairs, little houses, and myriad mites, p.325-351. In M.D. Lowman \& N.M. Nadkarni (eds.), Forest canopies. California, Academic Press, 624p.

Zacarias, M.S. \& G.J. de Moraes. 2002. Mite diversity (Arthropoda: Acari) on euphorbiaceous plants in three localities in the State of São Paulo. Biota Neotrop. 2:1-12.

Received 12/X/06. Accepted 18/V/07. 